\begin{tabular}{c|c|c}
\hline \hline Vol. 256: 183-191, 2003 & MARINE ECOLOGY PROGRESS SERIES \\
Mar Ecol Prog Ser & Published July 17 \\
\hline
\end{tabular}

\title{
The role of cryptobenthic reef fishes in coral reef trophodynamics
}

\author{
Martial Depczynski*, David R. Bellwood \\ Centre for Coral Reef Biodiversity, Department of Marine Biology, James Cook University, Townsville 4811, Australia
}

\begin{abstract}
An examination of the trophic status of a cryptobenthic reef fish community from the central Great Barrier Reef was carried out to evaluate the potential role of cryptobenthic fishes in coral reef ecosystems. Using frequency of occurrence data, dietary analyses revealed a diverse range of trophic groups, although detritivory (in 10 out of 16 species and $39.3 \%$ of individuals) and carnivory (5 of 16 species and $40.5 \%$ of individuals) clearly dominate as trophic modes. Herbivory ( 1 species; $2.4 \%$ of individuals) is only a minor component in the community trophic structure. Of the 18 dietary categories identified, detritus and copepods were the only constituents represented in all 16 species examined. Although the degree of dietary specialization varied among taxa, the 2 most abundant species, Eviota queenslandica and Istigobius goldmanni, utilised the broadest range of dietary items. Morphology reflected the trophic partitioning among fishes: carnivores were invariably $<28 \mathrm{~mm}$ total length (TL) and had gut-length ratios (GLRs) of $<0.5$; detritivores were all $>38 \mathrm{~mm}$ TL with GLRs generally exceeding $>1.0$. The trophic composition and numerical strength of the cryptobenthic fish fauna suggests that cryptobenthic reef fishes have the potential to make a significant contribution to reef trophodynamics along a number of trophic pathways. This prompts a re-evaluation of the roles of reef fishes in the functioning of coral reefs, particularly those related to the recycling of primary production through detrital pathways.
\end{abstract}

KEY WORDS: Detritus $\cdot$ Trophic $\cdot$ Detritivory $\cdot$ Herbivory $\cdot$ Diet $\cdot$ Gobiidae $\cdot$ Assemblages $\cdot$ Ecosystem function

Resale or republication not permitted without written consent of the publisher

\section{INTRODUCTION}

Despite the knowledge that a significant proportion of coral reef fish assemblages are composed of small, cryptic, benthic fishes, marine ecologists have focused almost entirely on the larger, more conspicuous members of the reef fish community (Sale 1991). This has resulted in a distorted and fragmented picture of reef fishes that is heavily biased towards larger species. Recently, an entire 'cryptobenthic' reef fish assemblage was quantitatively described for a fringing reef system on the Great Barrier Reef (Ackerman \& Bellwood 2000, 2002). Cryptobenthic fishes, defined as 'adult fishes of typically $<5 \mathrm{~cm}$ that are visually and/or behaviourally cryptic, and maintain a close association with the benthos', may be extremely abundant. Estimates of the numerical abundance and species richness of this cryptobenthic community were strikingly high, with an average of 95 individuals and 36 species in a $10 \mathrm{~m}^{2}$ area (Ackerman \& Bellwood 2000). This represents approximately $50.1 \%$ of individuals and $40.4 \%$ of all reef fish species at this location.

Apart from abundances and species richness at a single geographical location, we know very little of the ecology of cryptobenthic reef fish communities. As the standard visual censusing techniques employed in reef fish studies do not adequately census cryptic fishes, it is not surprising that our understanding of this component of the reef fish fauna is so limited. The difficulties involved with accurately sampling and identifying small, cryptic fishes and their omission from nondestructive censusing techniques explain much of the disparity and bias towards the larger, conspicuous fishes (Sale 1981, Bellwood 1996). In the absence of even rudimentary knowledge on most cryptobenthic fishes such as their densities, diets and distribution on 
coral reefs, their role in reef trophodynamics has been assumed to be a minor one (but see Townsend \& Tibbetts 2000 and Wilson et al. 2003). Their exclusion from studies focusing on community structure (e.g. Jones \& Chase 1975, Sheperd et al. 1992) and trophodynamics in particular, is evident in trophic models focusing on community dynamics and ecosystem energetics (e.g. Christensen \& Pauly 1992). These studies rarely acknowledge the absence of cryptobenthic fishes in their analyses.

Despite this obvious gap in our knowledge, the information to date suggests that the cryptobenthic community has the potential to make a significant and substantial contribution to reef ecosystem processes. In particular, their numerical strength has led to the suggestion that this group of fishes may play a significant role in reef trophodynamics, with up to $25 \%$ of the energy flow by fishes passing through these taxa (Ackerman \& Bellwood 2002). Estimates indicate that this reef fish component constitutes $9.7 \%$, or $20 \mathrm{~g} \mathrm{~m}^{-2}$ of overall reef fish biomass (Ackerman \& Bellwood 2000), an estimate similar to that recorded for mobile invertebrates on coral reefs ( 7.5 to $22.3 \mathrm{~g} \mathrm{~m}^{-2}$ ) (Klumpp et al. 1988, Riddle et al. 1990). It is widely considered that the contribution of cryptobenthic reef fishes to trophic pathways can be largely defined by their consumption of microcrustaceans and their status as prey items for larger reef fishes. Certainly their role as small carnivores is consistent with size-based expectations, as most small fishes are carnivorous, including juvenile herbivores (Choat 1991, Choat \& Clements 1998, Wainwright \& Bellwood 2002). However, a role in other trophic pathways has been documented, with cryptobenthic fishes in the family Blennidae, for example, accessing and utilising detritus as a major dietary component (Wilson 2000, Wilson et al. 2001a).

To date, no study has examined the trophic status of an entire cryptobenthic reef fish community in a way that permits their role in ecosystem trophodynamics to be evaluated. Without knowledge of the trophic status of this community it is difficult to identify their role in reef processes beyond a role as potential prey for larger taxa. Determining the diets of cryptobenthic fishes is an essential primary step in accurately assessing their potential importance in coral reef trophodynamics, and provides us with an enhanced opportunity to further define the role of reef fish populations in coral reef ecosystems.

In this study therefore, we utilised morphological and gut-content analyses of a range of dominant cryptobenthic reef fish species from the central Great Barrier Reef to assess the trophic status and structure of this community. The specific aims of this study were: (1) to identify the diets of the dominant cryptobenthic species; (2) to examine the extent and nature of dietary variability within this reef fish community; and (3) to assess their potential role as a functional group in the trophodynamics of a coral reef ecosystem.

\section{MATERIALS AND METHODS}

Collections. Collections were undertaken from March to July 2001 at 3 locations on the leeward side of Orpheus Island $\left(18^{\circ} 35^{\prime} \mathrm{S}, 146^{\circ} 28^{\prime} \mathrm{E}\right)$, central Great Barrier Reef, at depths of 6 to $9 \mathrm{~m}$. We identified 4 distinct habitats (sand and rubble, cave, open reef and soft coral) and sampled them all 7 times at each of the 3 locations $(n=84)$. Specimens were collected on SCUBA using clove oil and a fine-mesh net $(2 \mathrm{~mm})$ covering a basal area of $0.4 \mathrm{~m}^{2}$, giving a total sampling area of $33.6 \mathrm{~m}^{2}$ (modified after Ackerman \& Bellwood 2002). The net was placed in a circle on the substratum, before approximately $125 \mathrm{ml}$ of a 5:1 ethanol: clove-oil mixture was pumped into the netted area for approximately $20 \mathrm{~s}$. The mixture was allowed to sit inside the net for $1 \mathrm{~min}$ before the search for anaesthetised fishes began. This short duration reduced the potential for regurgitation of gut contents during anaesthesia. Individuals found in crevices and holes were carefully extracted using plastic cable ties. Fishes were placed in individually labelled clip-seal bags and placed in an ice-water slurry as soon as possible after capture. Individuals were then identified and put into a $10 \%$ formalin-seawater solution for $5 \mathrm{~d}$, then transferred into $70 \%$ ethanol. Identification of species was confirmed in the laboratory using taxonomic texts (Winterbottom 1985, Winterbottom \& Emery 1986, Randall et al. 1997, Meyers 1999), with the exception of Pleurosicya muscarum, which was identified by $\mathrm{H}$. Larson (Northern Territory Museum, Australia). Where identification to species level could not be established, forms were denoted Sp. A, Sp. B etc.

Gut-content analysis. The gut contents of 20 individuals from each of the 16 most abundant cryptobenthic species were examined (see Table 1). Of the 320 specimens used, 109 were obtained from previous samples taken from the same locations using comparable techniques (Ackerman \& Bellwood 2002). Samples were based exclusively on individuals collected either late in the morning, or in the afternoon.

Gut contents were quantified using methods developed for studies of other small taxa in the families Blennidae (Wilson 2000), Pomacentridae (Wilson \& Bellwood 1997) and Apogonidae (Marnane \& Bellwood 2002). Total lengths and intestine lengths of each individual were measured to $0.1 \mathrm{~mm}$ using vernier callipers. The intestine was opened lengthways and the entire contents removed, then agitated (to prevent stratification) and distributed evenly on a petri dish in 
the shape of a square. A transparent sheet with a similar-sized square containing a grid of 100 squares, of which 60 were randomly blacked out, was then placed over the gut contents. The gut content in a single point in each of the 40 transparent squares (topright corner of each grid square) was identified using a stereomicroscope (40x), and recorded. This technique provides a quantitative estimate of gut contents (20 individuals per species $\times 40$ squares per individual); 18 separate dietary components across a range of trophic groups (carnivores, herbivores and detritivores) were identified (see Table 2). Amorphous $(<250 \mu \mathrm{m})$ organic matter (AOM) was assigned to the detritivore food group and is defined as dead organic material lacking any identifiable form or structure (cf. Bowen 1984, Wilson 2000). Species were assigned to trophic categories based on the dominant ( $>50 \%$ mean occurrence) category in their diet.

Statistical analysis. Principal components analysis (PCA) based on a covariance matrix of the occurrence (number of cells occupied) for each dietary category in each species was generated using SPSS (Version 10.0). Linearity was checked using a series of scatterplots and found to be adequate after transformation of the data using $\log _{10}(x+1)$. To evaluate the relationship between diet and 2 morphological attributes, PC1 (describing the main source of variation in diet among species) was plotted against total lengths, and gut-length ratios (total length:gut length), for the 16 species.

\section{RESULTS}

A total of 458 individuals from 48 species in 11 families were collected. The 16 most abundant species, selected for gut content analysis, represented $84 \%$ of all individuals (Table 1). All but 3 belonged to the family Gobiidae, with gobiids comprising $85 \%$ of all individuals. The 3 most abundant species were all gobiids and, collectively, these species made up $51 \%$ of all specimens (Table 1).

A diverse range of species-specific dietary preferences was evident (Fig. 1), including specialised carnivores (e.g. Priolepsis nuchifasciatus and Pleurosicya muscarum), herbivores (Amblygobius rainfordi) and detritivores (e.g. Asterropteryx semipunctatus and Ecsenius mandibularis). Other species, however, including the 2 most abundant species, Eviota queenslandica and Istigobius goldmanni, appear to utilise a much broader range of dietary items. At the 2 extremes of generalists to specialists, I. goldmanni consumed 14 out of a possible 18 dietary components (Table 2), in contrast to $E$. mandibularis which fed on a total of 4 categories, with 1 (AOM) constituting $86 \%$ of its diet. The mean number of food categories utilised by all species was 13.6. AOM and copepods were the only dietary components represented in the diet of all 16 species.

The importance of detritus in the diets of all species is clearly evident (AOM: Fig. 1), ranging from $11 \%$ in Priolepsis nuchifasciatus to $86 \%$ in Ecsenius mandibularis, with a mean of $42.6 \%$ across all 16 species. Detritus was the dominant dietary component in 10 species (Assessor macneilli, Eviota queenslandica, Trimma caesiura, Istigobius goldmanni, Valenciennea muralis, I. decoratus, Bathygobius fuscus, Amblygobius nocturnis, Asterropteryx semipunctatus and E. mandibularis). The other major component, copepods, was dominant in 5 species (Priolepsis nuchifasciatus, Pleurosicya muscarum, Eviota sp. C., Enneapterygius tutuilae, and Trimma striata) and filamentous algae in only 1 (Amblygobius rainfordi). Sediment was found in a total of 12 species, filamentous algae in only 4 species.

PCA of these 16 species and the occurrence of the 18 dietary categories revealed a distinct division of species into 4 dietary groups (Fig. 2). Of these, 3 discrete trophic groups are immediately apparent: detritivory (Ecsenius mandibularis, Amblygobius nocturnis, Asterropteryx semipunctatus, Istigobius goldmanni, Valenciennea muralis, I. decoratus and Bathygobius fuscus), carnivory (Trimma striata, Eviota sp. C, Pleurosicya muscarum, Enneapterygius tutuilae and Priolepsis nuchifasciatus), and herbivory (Amblygobius rainfordi). The fourth group located centrally on the

Table 1. Families, species and numbers of individuals sampled for 16 dominant cryptobenthic reef fish species selected for gut-content analysis, and their contribution (\%) to total sample (of 458 individuals in 48 species). For gut-content analysis ( $n=20$ per species), the shortfall was made up from existing collections from same area (Ackerman \& Bellwood 2000, 2002). An expanded species list is given in Ackerman \& Bellwood (2002)

\begin{tabular}{|c|c|c|c|}
\hline Species & Family & $\begin{array}{c}\text { No. } \\
\text { sampled }\end{array}$ & $\begin{array}{c}\% \text { of total } \\
\text { species }\end{array}$ \\
\hline Eviota queenslandica & Gobiidae & 154 & 33.6 \\
\hline Istigobius goldmanni & Gobiidae & 47 & 10.3 \\
\hline Pleurosicya muscarum & Gobiidae & 32 & 7.0 \\
\hline Assessor macneilli & Plesiopidae & 19 & 4.2 \\
\hline Eviota sp. C & Gobiidae & 15 & 3.3 \\
\hline Enneapterygius tutuilae & Tripterygiidae & 14 & 3.1 \\
\hline Trimma caesiura & Gobiidae & 13 & 2.8 \\
\hline Priolepsis nuchifasciatus & Gobiidae & 13 & 2.8 \\
\hline Asterropteryx semipunctatus & Is Gobiidae & 13 & 2.8 \\
\hline Valenciennea muralis & Gobiidae & 11 & 2.4 \\
\hline Ecsenius mandibularis & Blennidae & 11 & 2.4 \\
\hline Trimma striata & Gobiidae & 10 & 2.2 \\
\hline Amblygobius rainfordi & Gobiidae & 10 & 2.2 \\
\hline Amblygobius nocturnis & Gobiidae & 9 & 2.0 \\
\hline Istigobius decoratus & Gobiidae & 7 & 1.5 \\
\hline \multirow[t]{2}{*}{ Bathygobius fuscus } & Gobiidae & 6 & 1.3 \\
\hline & & 384 & 83.9 \\
\hline
\end{tabular}




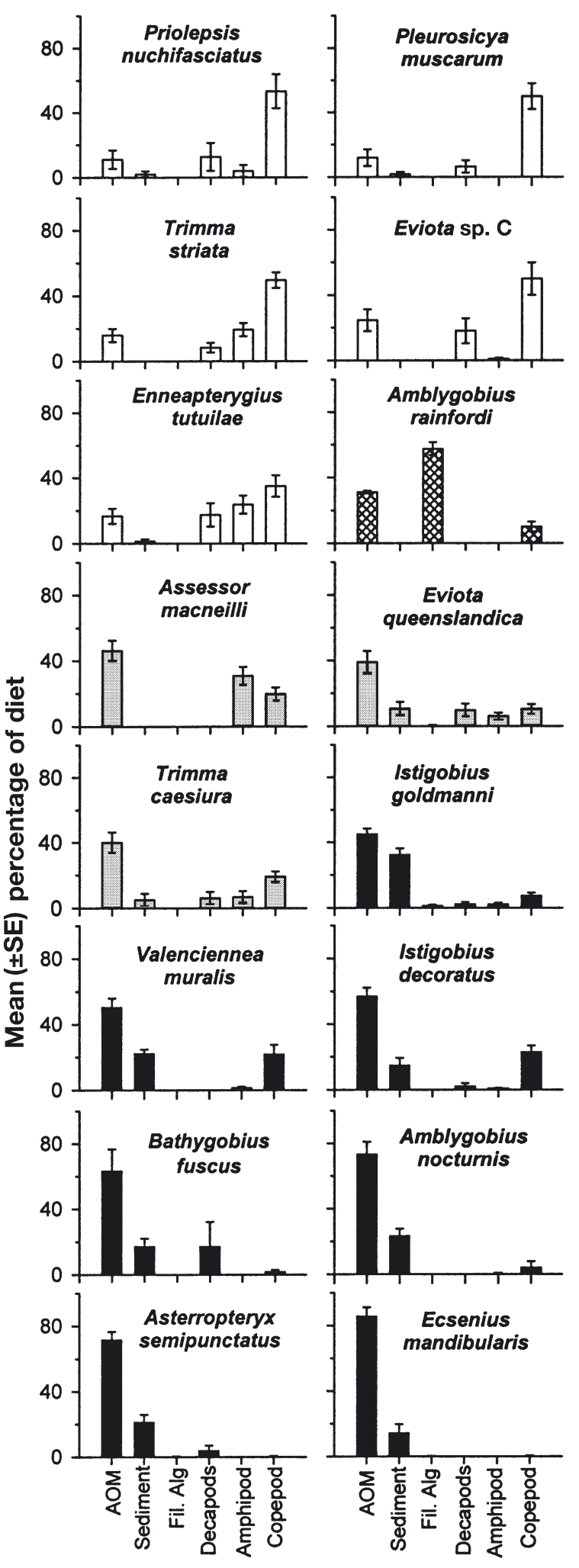

Fig. 1. Distribution of major dietary items in 16 cryptobenthic reef fish species (each species $\mathrm{n}=20$ ). White bars: carnivores; cross-hatched: herbivores; grey: generalist feeders; black: detritivores (classified as in Figs. 2 \& 3). AOM: amorphous organic matter; Fil. Alg: filamentous algae biplot (T. caesiura, Eviota queenslandica and Assessor macneilli) indicates that a broad range of dietary items are equally represented in the diets of these species. PC1 explains $57.3 \%$ of the variation in diet among species: negative scores correspond to those species that feed heavily on detrital matter (AOM) and sediment. Those with positive scores feed heavily on a carnivorous diet of copepods, amphipods and other crustaceans. PC2 explains $19.6 \%$ of the variation, positive scores reflecting a high proportion of filamentous algae in the diet. These results clearly identify AOM and copepods as the dominant dietary components in the cryptobenthic community.

Species-specific trophic patterns identify detritivory as the dominant trophic category among species (7 of the 16 species), followed closely by carnivory (5 of the 16 species: Fig. 1). When taking species abundances into consideration, however, carnivory marginally dominates the trophic structure of cryptobenthic fishes, although the pattern remains similar (Fig. 3), with $39.3 \%$ of the diets of all individuals analysed being in the detrital category and $45.0 \%$ in the carnivorous category. Subtracting the influence of the numerically dominant Eviota queenslandica (33.6\% of all individuals collected) changes this trend little, with detrital items averaging $40.5 \%$ among individuals and carnivorous items $42.8 \%$. Overall, both detritivory and carnivory are highly represented among both species and individuals within the cryptobenthic reef fish community. Herbivory, represented by just 1 species and

Table 2. Dietary components and their assigned trophic groups. Sediment was quantified and recorded, but not assigned to any trophic group because of its uncertain nutritional value. 'Other' includes echinoderms, fishes, fish scales, tunicates, nematodes, sponges, bryozoans and annelids other than polychaetes. Combined with unidentified material, this category equates to $1.6 \%$ of overall dietary assemblage

\begin{tabular}{|lc|}
\hline Dietary components & Assigned trophic group \\
\hline Amorphous organic matter (AOM) & Detritivore \\
Sediment & Nil \\
Gastropods & Carnivore \\
Bivalves & Carnivore \\
Copepods & Carnivore \\
Amphipods & Carnivore \\
Isopods & Carnivore \\
Ostracods & Carnivore \\
Decapods & Carnivore \\
Polychaetes & Carnivore \\
Foraminiferans & Carnivore \\
Filamentous algae & Herbivore \\
Nonfilamentous algae & Herbivore \\
Dinoflagellates & Herbivore \\
Eggs & Carnivore \\
Diatoms & Herbivore \\
Other & Nil \\
Unidentified & Nil \\
\hline
\end{tabular}


$2.4 \%$ of individuals, appears to be a minor trophic pathway within this community.

The relationship between diet, as expressed by the score on PC1, and total length, TL (Fig. 4a), and diet and gut-length ratio (gut length:TL) (Fig. 4b) revealed a distinctive and consistent relationship between diet and the 2 morphological parameters. Without exception, species with a carnivorous diet (Pleurosicya muscarum, Enneapterygius tutuilae, Priolepsis nuchifasciatus, Eviota sp. C and Trimma striata) were small (<28 mm TL) (Fig. 4a) and had small gut length ratios (GLRs) of less than 0.5 (Fig. 4b). At the other extreme, detrital feeders (Istigobius goldmanni, Asterropteryx semipunctatus, Valenciennea muralis, Ecsenius mandibularis, Amblygobius nocturnis, Bathygobius fuscus, and $I$. decoratus) were larger, at least $38 \mathrm{~mm}$ TL (Fig. 4a), with GLRs of $\geq 1.0$ (Fig. 4b). E. mandibularis, a detrital specialist $(85.5 \%$ of diet) showed the most extreme GLR (2.9) of all the species examined. Exceptions to this general relationship existed in the TLs of 2 generalist feeders, T. caesiura and Assessor macneilli (Fig. 4a), and the GLR's of 2 detritivores, V. muralis and I. goldmanni (Fig. 4b), reflecting the generalist dietary habits of these 4 species (cf. Fig. 1). Amblygobius rainfordi, the only herbivore, had the longest TL of all species examined; however, its GLR was markedly smaller $(<0.9)$ than that of the detritivores.

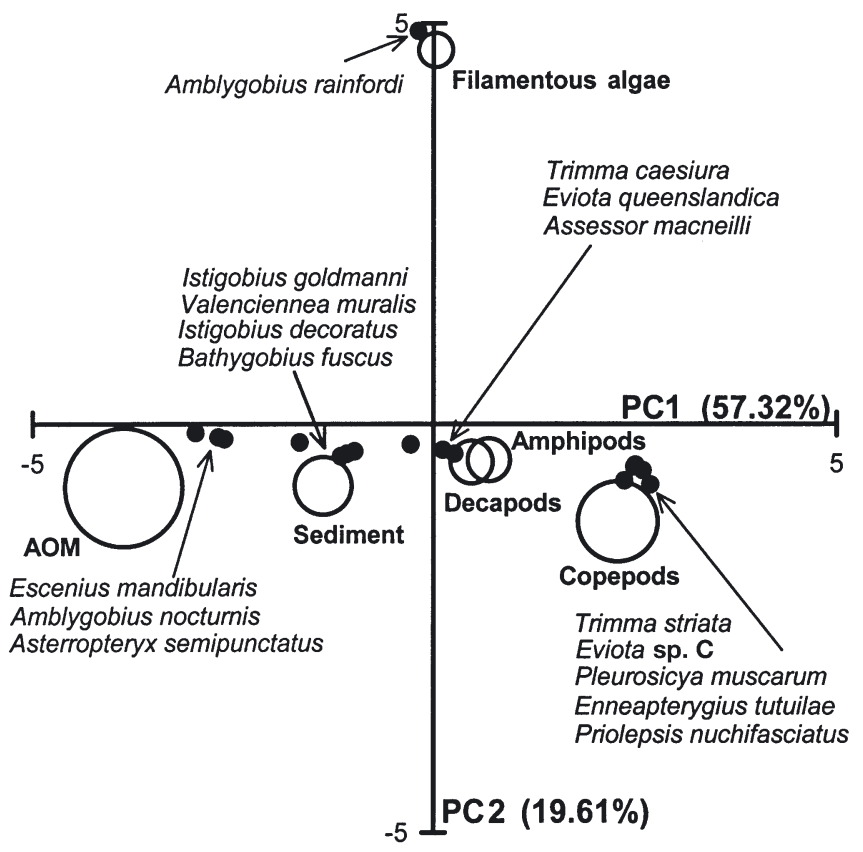

Fig. 2. Principal components biplot based on dietary composition of 16 cryptobenthic species selected for gut-content analysis; (-) position of taxa. Analysis is based on all 18 dietary categories (Table 2$)$; $(O$, varying sizes) 6 dominant food-category vectors; circle diameters scaled (square-root transformation) to indicate proportional importance of various dietary categories among all individuals in the 16 species

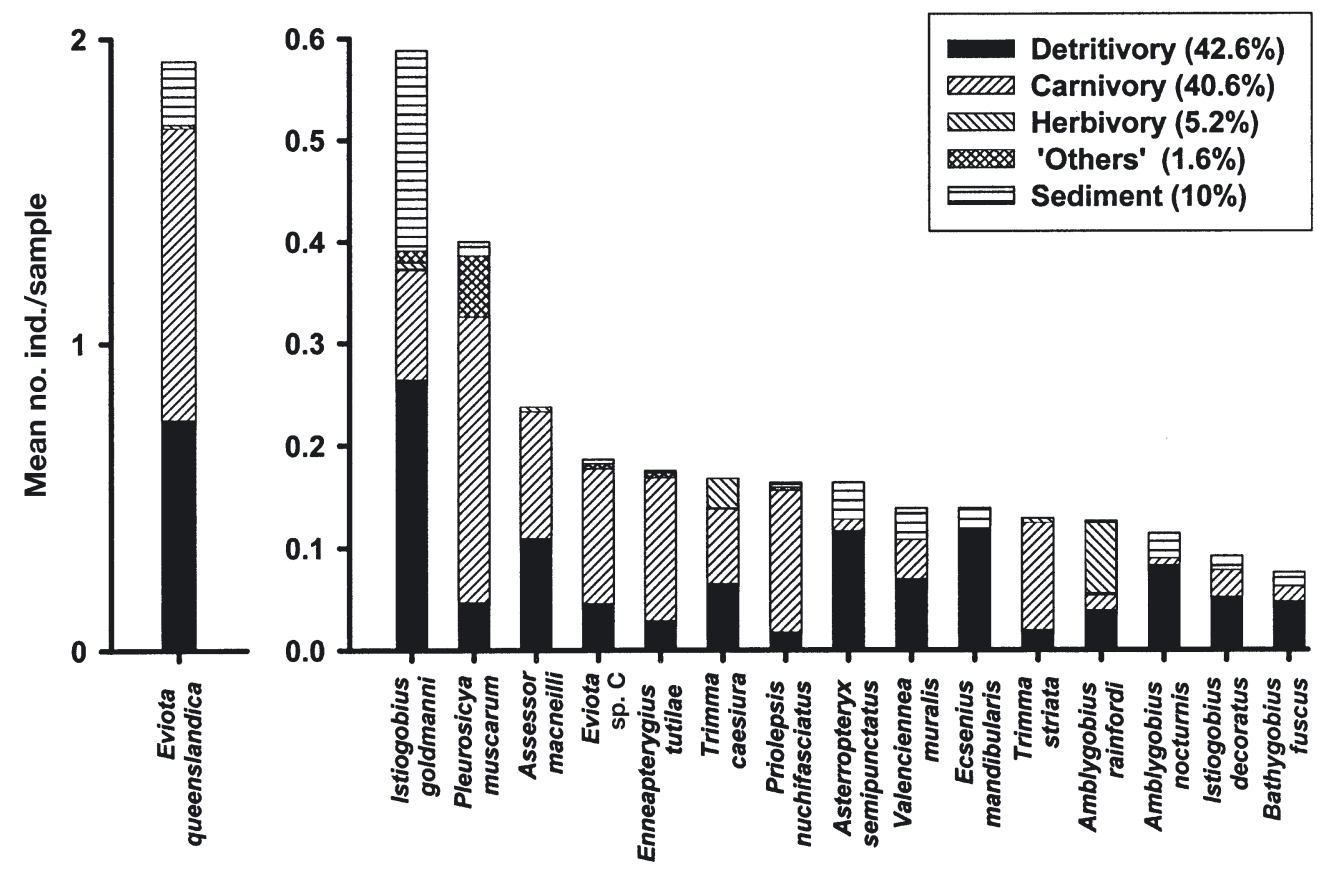

Fig. 3. Mean number of individuals caught per sample $(n=80$ samples) and their trophic composition based on 18 different food categories (Table 2). 'Others' includes both unidentified material and a range of minor dietary items. Sediment included to indicate proportion of largely inorganic material ingested. Percentages in key indicate mean importance of each major trophic category among the 16 species. Note different scale for Eviota queenslandica, indicative of its dominant status within the cryptobenthic reef fish community 

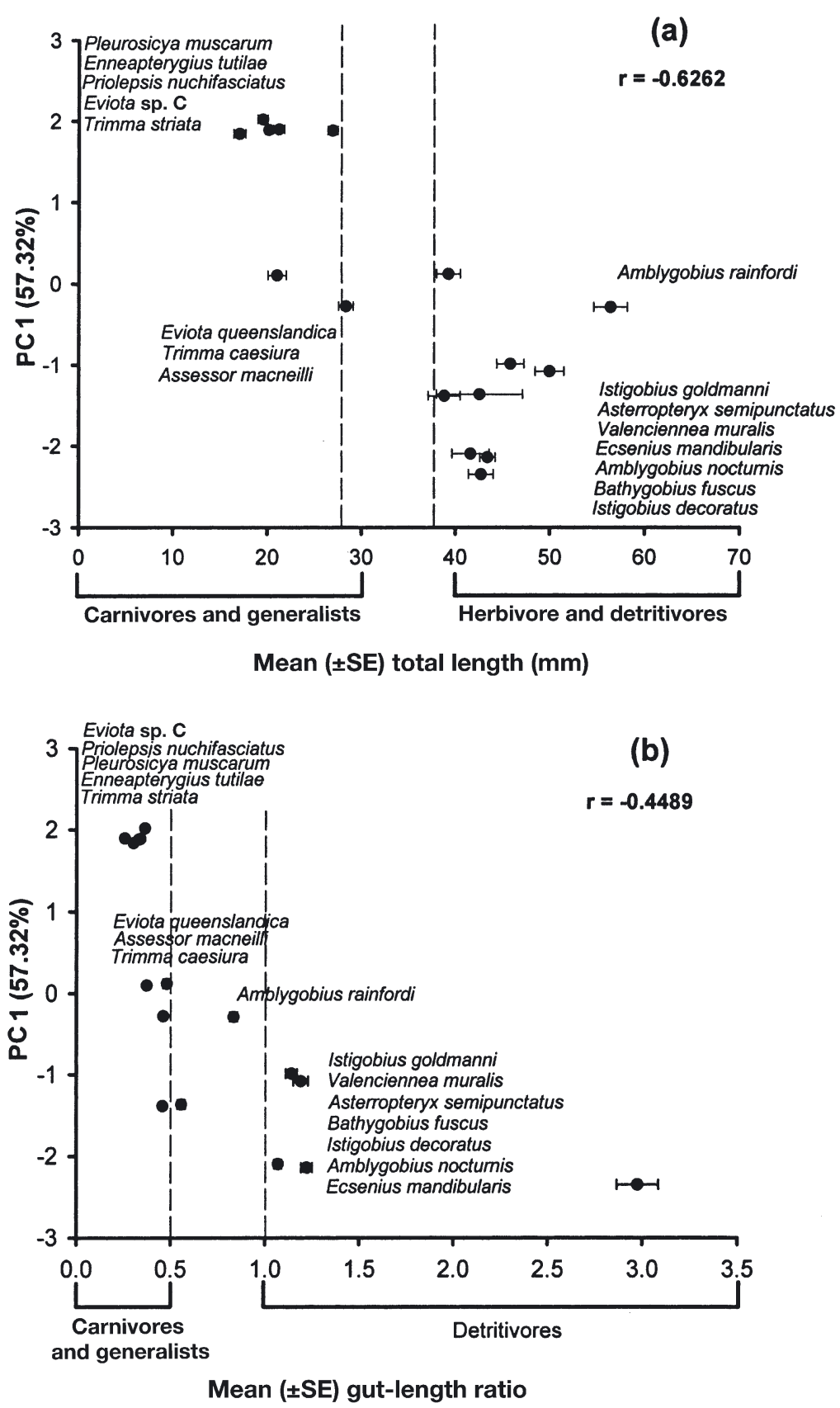

Fig 4. Diet, expressed by PC1 scores (Fig. 2) describing major source of variation in diets among species versus (a) mean $( \pm \mathrm{SE})$ total length $(\mathrm{mm})$, and (b) mean $( \pm \mathrm{SE})$ gut length ratio (gut length:total length). Species names (top to bottom) correspond with data points from left to right

\section{DISCUSSION}

The diets of cryptobenthic species were surprisingly diverse, encompassing a full range of trophic food groups. Despite the presence of a wide range of dietary items in the intestines of most species, detritus followed by copepods overwhelmingly dominated the diets of the 16 species examined. The presence of detritus as the dominant constituent is striking. The diets of small benthic fishes from a diverse range of ecosystems have long been thought to be restricted to micro-invertebrates (Targett 1981, Angermeier 1982, St. John et al. 1989). The role of detritus and detritivores has received relatively little attention, particularly in the marine environment. For this cryptobenthic reef fish community, however, the high detrital presence within and among species clearly identifies detritus as an important food source for small reef fishes.

Despite invertebrates offering the highest yield in terms of energy and nutritional requirements (Bowen et al. 1995, Choat \& Clements 1998), detrital feeding offers some clear advantages that are likely to be of benefit to small reef fish species. The abundant and widespread distribution of detritus is chief amongst these (see Purcell \& Bellwood 2001), offering a dependable food source that requires limited foraging, movement and handling, thereby reducing energy expenditure and minimising the risk of predation. Similarly, in comparison to an algalbased diet, detritus offers both increases in protein nutrient quality (Wilson \& Bellwood 1997, Crossman et al. 2001) and relative ease of assimilation (D'Avanzo \& Valiela 1990). In addition, smaller particle sizes (Choat \& Clements 1998, Wilson 2000), lower incidences of refractory material (Bowen 1984), and a reduction in the concentration of antiherbivore secondary metabolites (Hay \& Fenical 1988, Wilson et al. 2003) are likely to further enhance the ingestion and assimilation rates of detritus and boost its nutritional value per unit weight.

Although this study clearly identifies the potential for detritivory to be a significant trophic mode for cryptobenthic reef fishes, a predominantly detritivorous diet may also present a number of challenges. For example, detritivores must overcome the difficulties associated with the large proportion of inorganic and indigestible material typically found in detrital aggregates (Purcell \& Bellwood 2001). Consequently, strategies such as increased ingestion and throughput rates, selection for nutritionally rich detritus, or highly efficient nutrient assimilation rates may be a pre-requisite to the successful utilisation of detritus as a sole or principal dietary constituent. Although estimates of consumption rates for detritivorous fishes are limited (but see Klumpp \& Polunin 
1990), many herbivorous fish species are known to increase their consumption by prolonging feeding bouts or reverting to occasional carnivory to supplement any nutritional shortfalls (Mundahl \& Wissing 1987, Horn 1989). In the case of the cryptobenthic community, diets based predominantly on detritus are invariably nutritionally enhanced with invertebrates to some degree.

In considering the diets of small fishes, a number of scale-related issues need to be taken into consideration. Small size may impose limitations on the range of dietary categories available to the cryptobenthic reef fish community. For example, the mechanical strength needed to tear algal thalli from the substratum may exclude most small fishes from herbivory. Decreased motility may also reduce their potential to exploit rarer or more patchily distributed food resources. Furthermore, because both growth and metabolic rates scale allometrically relative to decreasing body size (McNab 1983, Griffiths 1992), relative energy requirements and growth rates are much higher in smaller vertebrates (Miller 1996), and the capacity for fat reserves limited or non-existent (Webster 1974). Under these conditions, a close association with a predictable, ubiquitous and abundant food supply that is easy to procure would be a considerable advantage. Detritus appears to fill this role for the cryptobenthic reef fish community in our study. It is present not only within the epilithic algal matrix (sensu Wilson \& Bellwood 1997) on hard substrata, but also on soft sediments. This permits a greater range of habitats to be exploited as foraging areas by species capable of utilising detritus as a significant food resource.

Previous studies suggest that nutrient quality and food selectivity are correlated and, as such, are likely to influence selectivity in the diet of particular organisms (Hughes 1980, Moriaty 1982, Bruggemann et al. 1994). From a theoretical point of view, detritivory appears to be a logical feeding mode for small reef fish species and is consistent with the results found in this study. In contrast, herbivory provides an altogether more demanding set of challenges for small reef fishes, including the difficulties involved with the digestion of intact cellular tissue, procurement of algae, and the presence of secondary metabolites. The only herbivore found among the cryptobenthic community examined in this study, Amblygobius rainfordi, with an average total length of $56 \mathrm{~mm}$ (smallest $45.4 \mathrm{~mm} \mathrm{TL}$ ) may define the lower size-limit for a herbivorous marine vertebrate and represents the smallest documented adult size for a herbivorous marine fish (cf. Horn 1989, Choat 1991).

We found a clear relationship between diet and 2 morphological attributes - total length and gutlength ratio. Of the species examined, total length was longer and gut-length ratios considerably higher in detritivores than in either generalist feeders, carnivores, or the sole herbivore. Gut-length ratios, in particular, are strongly correlated with diet, with a lengthening of the gut being associated with an apparent shift from carnivory towards detritivory. This correlation conforms to a previously described relationship between diet and gut length in fishes (Horn 1989, Carrasson \& Matallanas 1994). Ontogenetic shifts from a carnivorous to a herbivorous (Montgomery 1977, Bellwood 1988), or detritivorous (Zismann et al. 1975, Gerking 1994) diet, has long been associated with an increase in gut length ratios. Documented trends for fish species rank planktivores, carnivores, omnivores, and herbivores in order of increasing gut-length ratios (Elliott \& Bellwood in press). In the cryptobenthic fish community examined, it appears that detritivores appear after herbivores in this continuum. The clear relationship between gut length and diet in cryptobenthic fishes strongly suggests that detritus is a staple component of the diet of cryptobenthic fishes, as the appropriate morphological modifications are present for its efficient digestion and assimilation.

The key to maximising nutrient uptake in smaller detritivorous reef fish species may rely on the simple morphology provided by the gut. The passage of digestibles through a long, yet comparatively narrow gut provides an increased opportunity for higher rates of assimilation. The maintenance of close contact between ingesta and intestinal walls throughout the entire alimentary tract may provide a means of maximising nutrient uptake. An alternate hypothesis explaining highly efficient assimilation rates within simple gut morphologies is provided by Tibbetts (1997) for the herbivorous species Arrhamphus sclerolepis kreffti. In this species, digestion, transportation and subsequent absorption of nutrients takes place across a mucous layer which sheathes the entire gut contents, bypassing normal surface area to volume restrictions. A similar mucous layer is seen in many of the cryptobenthic species. These simple digestive strategies may help explain the prevalence and success of detritivores in the cryptobenthic community, although further research in this area is certainly warranted.

It is now known that detritus is a major component in the diets of numerous reef fishes, including pomacentrids (Wilson \& Bellwood 1997), blennies (Wilson 2000, Wilson et al. 2001a,b), acanthurids and scarids (Choat et al. 2002) and now, it appears, gobies. Many terrestrial and freshwater systems are based on detritus as the foundation for food webs, with detritivory constituting the most significant trophic pathway for the recycling of primary productivity (Bowen 1983, Baird \& Ulanowicz 1993, Hairstone \& Hairstone 1993). This raises the question as to whether detrital pathways 
might be of comparable importance on coral reefs. Modelling studies suggest that 59 to $69 \%$ of primary productivity on coral reefs is processed through detrital-based food webs and that detritivory exceeds herbivory by an overwhelming factor of 10:1 in fringing reef areas (Arias-Gonzalez et al. 1997). The high incidence of detritivory and the skewed detritivore:herbivore ratio in the cryptobenthic reef fish community combined with the recent studies of larger taxa (Wilson \& Bellwood 1997, Choat et al. 2002, Wilson et al. 2003) suggests that detritivory on reefs may approach these modelling predictions.

It must be noted that we define detritus based on the presence of at least $50 \%$ detritus (AOM) in the diet. The ability of these species to assimilate this material and the extent to which they rely on detritus as a dietary constituent remains to be determined. Nevertheless, it is highly likely that this detritus represents a significant source of nutrients for these species. It has been demonstrated that detritus on coral reefs is potentially as nutritious as algae (Wilson \& Bellwood 1997, Purcell \& Bellwood 2001, Wilson 2000, 2002, Crossman et al. 2001, Wilson et al. 2003), that several species preferentially select this detrital material (Purcell \& Bellwood 1993, Wilson \& Bellwood 1997, Wilson 2000, Wilson et al. 2003), and that in some species the detritus is assimilated and represents a major dietary constituent (Wilson et al. 2001a,b, Choat et al. 2002). In at least 1 cryptobenthic species, Salarias patzeneri, detritus is the principal food resource (Wilson 2000, Wilson et al. 2001a,b). The data herein suggests that this may be the rule rather than the exception for many cryptobenthic reef fishes.

The evidence presented in the present study helps to clarify the role of cryptobenthic reef fish communities in reef trophodynamics and ecosystem function. Previously it was assumed that their role was restricted to the transfer of energy along a single carnivorous trophic pathway (as predators of small crustaceans and prey for piscivores). Our cryptobenthic reef fish community appears to be primarily composed of detritivores, although it also contains species with a range of other trophic modes. The numerical abundance of these fishes and their theorised role as prey for larger reef fishes implies that the cryptobenthic reef fish community is a major and important contributor to several trophic pathways, including the recycling of primary productivity through detrital pathways. Determination of the spatial organisation and demographic patterns of this community will further clarify the relative importance of their contribution and is the next logical step in quantifying the role of this community in reef ecosystem function. The question of which trophic reef fish group dominates the harvesting of primary production on coral reefs has been raised by several authors (Wilson \& Bellwood 1997, Choat \& Clements 1998, Crossman et al. 2001, Purcell \& Bellwood 2001, Choat et al. 2002, Wilson et al. 2003). Central to this question is the role of the cryptobenthic reef fish community. With their numerical abundance, rapid growth, high turnover rates, and the high incidence of detritus in their diets, cryptobenthic reef fishes lend further weight to the suggestion that detritivory is a major trophic pathway on coral reefs. In this system, cryptobenthic fishes offer an unseen and previously overlooked link in coral reef trophodynamics.

Acknowledgements. We thank the staff of Orpheus Island Research Station and R. Eyre, A. Limbourne, J. Salmond, J. Scott and the Biology of Reef Fishes students at James Cook University for field support; J. Ackerman, O. Bellwood, D. Ceccarelli, J. Elliot, C. Fulton, A. Hoey, M. Marnane and S. Wilson for helpful discussions; J. Ackerman, P. Munday and $\mathrm{H}$. Larson for help with taxonomic identifications and M. Sheaves for statistical advice. This study was funded by the Australian Research Council (D.R.B.), a Reef CRC Augmentative grant and James Cook University. JCU Experimentation Ethics Review Committee Approval \#A428.

\section{LITERATURE CITED}

Ackerman JL, Bellwood DR (2000) Reef fish assemblages: a re-evaluation using enclosed rotenone stations. Mar Ecol Prog Ser 206:227-237

Ackerman LJ, Bellwood DR (2002) Comparative efficiency of clove oil vs rotenone for sampling tropical reef fish assemblages. J Fish Biol 60:893-901

Angermeier PL (1982) Resource seasonality and fish diets in an Illinois stream. Environ Biol Fish 7:251-264

Arias-Gonzalez JE, Delesalle B, Salvat B, Galzin R (1997) Trophic functioning of the Tiahura reef sector, Moorea Island, French Polynesia. Coral Reefs 16:231-246

Baird D, Ulanowicz RE (1993) Comparative study on the trophic structure, cycling and ecosystem properties of four tidal estuaries. Mar Ecol Prog Ser 99:221-237

Bellwood DR (1988) Ontogenetic changes in the diet of early post-settlement Scarus species (Pisces: Scaridae). J Fish Biol 33:213-219

Bellwood DR (1996) The Eocene fishes of Monte Bolca - the earliest coral reef fish assemblage. Coral Reefs 15:11-19

Bowen SH (1983) Detritivory in neotropical fish communities. Environ Biol Fish 9:137-144

Bowen SH (1984) Evidence of a detritus food chain based on consumption of organic precipitates. Bull Mar Sci 35: 440-448

Bowen SH, Lutz EV, Ahlgren MO (1995) Dietary protein and energy as determinants of food quality: trophic strategies compared. Ecology 76:899-907

Bruggemann JH, van Oppen MJH, Breeman AM (1994) Foraging by the spotlight parrotfish Sparisoma viride. I. Food selection in different, socially determined habitats. Mar Ecol Prog Ser 106:41-55

Carrason M, Matallanas J (1994) Morphometric characteristics of the alimentary tract of deep-sea Mediterranean teleosts in relation to their feeding habits. Mar Biol 118:319-322

Choat JH (1991) The biology of herbivorous fishes on coral reefs. In: Sale PF (ed) The ecology of reef fishes on coral reefs. Academic Press, San Diego, p 120-155 
Choat JH, Clements KD (1998) Vertebrate herbivores in marine and terrestrial environments: a nutritional ecology perspective. Annu Rev Ecol Syst 29:375-403

Choat JH, Clements KD, Robbins WD (2002) The trophic status of herbivorous fishes on coral reefs. I. Dietary analysis. Mar Biol 140:613-623

Christensen V, Pauly D (1992) ECOPATH II - a model for balancing steady-state ecosystem models and calculating network characteristics. Ecol Model 61:169-185

Crossman DJ, Choat JH, Clements KD, Hardy T, McConchie J (2001) Detritus as food for grazing fishes on coral reefs. Limnol Oceanogr 46:1596-1605

D'Avanzo C, Valiela I (1990) Use of detrital foods and assimilation of nitrogen by coastal detritivores. Estuaries 13:20-24

Elliott JP, Bellwood DR (2003) Alimentary tract morphology and diet in three coral reef fish families. J Fish Biol

Gerking SD (1994) Feeding ecology of fishes. Academic Press, San Diego

Griffiths D (1992) Size, abundance, and energy use in communities. J Anim Ecol 61:307-315

Hairstone NG Jr, Hairstone NG Sr (1993) Cause-effect relationships in energy flow, trophic structure, and interspecific interactions. Am Nat 142:379-411

Hay ME, Fenical W (1988) Marine plant-herbivore interactions: the ecology of chemical defense. Annu Rev Ecol Syst 19:111-145

Horn MH (1989) Biology of marine herbivorous fishes. Oceanogr Mar Biol Annu Rev 27:167-272

Hughes RN (1980) Optimal foraging theory in the marine context. Oceanogr Mar Biol Annu Rev 18:423-481

Jones RS, Chase JA (1975) Community structure and distribution of fishes in an enclosed high island lagoon in Guam. Micronesica 11:127-148

Klumpp DW, Polunin NVC (1990) Algal production, grazers and habitat partitioning on a coral reef: positive correlation between grazing rate and food availability. In: Barnes M, Gibson RN (eds) Trophic relationships in the marine environment. University of Aberdeen Press, Aberdeen, p 372-388

Klumpp DW, McKinnon AD, Mundy CN (1988) Motile cryptofauna of a coral reef: abundance, distribution and trophic potential. Mar Ecol Prog Ser 45:95-108

Marnane MJ, Bellwood DR (2002) Diet and nocturnal foraging in cardinalfishes (Apogonidae) at One Tree Reef, Great Barrier Reef, Australia. Mar Ecol Prog Ser 231: 261-268

McNab BK (1983) Energetics, body size, and the limits to endothermy. J Zool 199:1-29

Meyers RF (1999) Micronesian reef fishes: a comprehensive guide to the coral reef fishes of Micronesia, 3rd edn. Coral Graphics, Barrigada, Guam

Miller PJ (1996) The functional ecology of small fish: some opportunities and consequences. Symp Zool Soc 69: 175-199

Montgomery WL (1977) Diet and gut morphology in fishes, with special reference to the monkeyface prickleback, Cebidichthys violaceus (Stichaeidae: Blennioidei). Copeia 1:178-182

Moriaty DJW (1982) Feeding of Holothuria atra and Stichopus chloronotus on bacteria, organic carbon and organic nitrogen in sediments of the Great Barrier Reef. Aust J Mar Freshw Res 33:255-263

Mundahl ND, Wissing TE (1987) Nutritional importance of detritivory in the growth and condition of gizzard shad in an Ohio reservoir. Environ Biol Fish 20:129-142

Editorial responsibility: Kenneth Tenore (Contributing Editor), Solomons, Maryland, USA
Purcell SW, Bellwood DR (1993) A functional analysis of food procurement in two surgeonfish species, Acanthurus nigrofuscus and Ctenochaetus striatus (Acanthuridae). Environ Biol Fish 37:139-159

Purcell SW, Bellwood DR (2001) Spatial patterns of epilithic algal and detrital resources on a windward coral reef. Coral Reefs 20:117-125

Randall JE, Allen GR, Steene EC (1997) Fishes of the Great Barrier Reef and Coral Sea. Crawford House Publishing, Bathurst

Riddle MJ, Alongi DM, Dayton PK, Hansen JA, Klumpp DW (1990) Detrital pathways in a coral reef lagoon I. Macrofaunal biomass and estimates of production. Mar Biol 104: $109-118$

Sale PF (1981) Precision and accuracy of visual census technique for fish assemblages on coral patch reefs. Environ Biol Fish 6:333-339

Sale PF (1991) The ecology of fishes on coral reefs. Academic Press, Sydney

Sheperd ARD, Warwick RM, Clarke KR, Brown BE (1992) An analysis of fish community responses to coral mining in the Maldives. Environ Biol Fish 33:367-380

St John J, Jones GP, Sale PF (1989) Distribution and abundance of soft-sediment meiofauna and a predatory goby in a coral reef lagoon. Coral Reefs 8:51-57

Targett TE (1981) Trophic ecology and structure of coastal Antarctic fish communities. Mar Ecol Prog Ser 4:243-263

Tibbetts IR (1997) The distribution and function of mucous cells and their secretions in the alimentary tract of Arrhamphus sclerolepis krefftii. J Fish Biol 50:809-820

Townsend KA, Tibbetts IR (2000) Biomass and distribution of herbivorous blennies in the southern Great Barrier Reef. J Fish Biol 56:774-791

Wainwright PC, Bellwood DR (2002) Ecomorphology of feeding in coral reef fishes. Chapter 2. In: Sale PF (ed) Coral reef fishes. Dynamics and diversity in a complex ecosystem. Academic Press, San Diego, p 33-55

Webster M (1974) Comparative vertebrate morphology. Academic Press, London

Wilson SK (2000) Trophic status and feeding selectivity of blennies (Blenniidae: Salariini). Mar Biol 136:431-437

Wilson S (2002) Nutritional value of detritus and algae in blenny territories on the Great Barrier Reef. J Exp Mar Biol Ecol 271:155-169

Wilson SK, Bellwood DR (1997) Cryptic dietary components of territorial damselfishes (Pomacentridae, Labroidei). Mar Ecol Prog Ser 153:299-310

Wilson S, Burns K, Codi S (2001a) Sources of dietary lipids in the coral reef blenny Salarias patzneri. Mar Ecol Prog Ser 222:291-296

Wilson S, Burns K, Codi S (2001b) Identifying sources of organic matter in sediments from a detritivorous coral reef fish territory. Org Geochem 32:1257-1269

Wilson SK, Bellwood DR, Choat JH, Furnas MJ (2003) Detritus in the epilithic algal matrix and its use by coral reef fishes. Oceanogr Mar Biol Annu Rev 41:279-309

Winterbottom R (1985) Two new gobiid fish species (in Priolepsis and Trimma) from the Chagos Archipelago, Central Indian Ocean. Can J Zool 63:748-754

Winterbottom R, Emery AR (1986) Review of the gobioid fishes of the Chagos Archipelago, Central Indian Ocean. Contrib R Mus Life Sci 142:1-82

Zismann L, Berdugo V, Kimor B (1975) The food and feeding habits of early stages of grey mullets in the Haifa Bay region. Aquaculture 6:59-75

Submitted: May 16, 2002; Accepted: February 25, 2003

Proofs received from author(s): June 24, 2003 